УДК 378.147

DOI https://doi.org/10.26661/2522-4360-2021-2-40

\title{
ІНТЕГРАЦІЯ ОЧНОЇ ТА ДИСТАНЦЙНОЇ ФОРМ НАВЧАННЯ УКРАЇНСЬКОЇ МОВИ ЯК ІНОЗЕМНОЇ
}

\author{
Уварова Т. Ю. \\ кандидат педагогічних наук, \\ доцент кафедри мовної підготовки \\ Харківський начіональний автомобільно-дорожній університет \\ вул. Ярослава Мудрого, 25, Харків, Україна \\ orcid.org/0000-0001-8502-2441 \\ uvarova_hnadu@ukr.net
}

Ключові слова: дистанційне
навчання, засоби,
дистанційний курс, украӥнська
мова як іноземна,
студенти-нефілологи.
Стаття присвячена питанню інтеграції очної та дистанційної форм навчання української мови як іноземної. Розглядається оновлення сучасних навчальних технологій, а також необхідність використання новітніх засобів формування комунікативної компетентності іноземних студентів під час їх навчання в закладах вищої освіти України. Аналізується проблема застосування засобів дистанційного навчання під час викладання української мови як іноземної студентів нефілологічних спеціальностей, а також впровадження електронних дистанційних курсів у навчальний процес іноземців. Відзначаються переваги та недоліки дистанційного навчання. Обгрунтовується думка, що дистанційне навчання має ряд переваг, а саме: доступність курсу в будь-який момент; необмеженість наданої інформації; оперативність надання інформації; гнучкість організації навчального процесу; автоматизація навчального процесу; мультимедійність. Порівнюється низка трактувань поняття «дистанційне навчання», його концепція та форми реалізації, які наводяться різними науковцями.

Наводиться приклад упровадження дистанційного курсу з української мови як іноземної для студентів заочної форми навчання. Описуються методи, застосовані для перевірки ефективності курсу, а саме: пілотний проект навчання з використанням авторського дистанційного курсу, що висвітлює ефективність творчих комунікативних і професійно-орієнтованих завдань; командно-змагальне навчання; моніторинг навчального процесу. Характеризується програма дистанційного курсу з української мови та його структура. Показується, що створення постійного комунікативного процесу з елементами співпраці значно підвищує мотивацію виконання завдань для самостійної роботи та забезпечує особистісну включеність студентів у безперервну інформаційно-мовленнєву діяльність в інтерактивному режимі виконання завдань. Доводиться ефективність комбінованого виду навчання. Наводиться низка доводів на доказ того, що впровадження дистанційного навчання сприятиме успішній адаптації іноземних студентів до навчання у ЗВО України. 


\title{
INTEGRATION OF FULL-TIME AND DISTANCE LEARNING OF THE UKRAINIAN LANGUAGE AS A FOREIGN
}

\author{
Uvarova T. Yu. \\ $\mathrm{PhD}$ in Pedagogy, \\ Associate Professor at the Departament of Language Training \\ Kharkiv National Automobile and Highway University \\ Yaroslava Mudrogo st, 25, Ukraine, Kharkov \\ orcid.org/0000-0001-8502-2441 \\ uvarova_hnadu@ukr.net
}

Key words: distance learning, tools, distance course, Ukrainian as a foreign language, non-philologists.
The article is devoted to the issue of integration of full-time and distance learning of the Ukrainian language as a foreign. The update of modern educational technologies is considered, as well as the need to use the latest means of forming the communicative competence of foreign students during their studies in higher education institutions of Ukraine. The problem of using distance learning tools during teaching Ukrainian as foreign students of non-philological specialties, as well as introduction of electronic distance courses in the educational process of foreigners is analyzed. The advantages and disadvantages of distance learning are noted. The opinion is substantiated that distance learning has several advantages, namely: the availability of the course at any time; unlimited information provided; promptness of information provision; flexibility of educational process organization; automation of the educational process; multimedia. A number of interpretations of the concept of «distance learning», its concept and forms of implementation, which are given by different sciences, are compared.

An example of the introduction of a distance course of the Ukrainian language as a foreign for students of correspondence form of study is given. The methods used to check the effectiveness of the course are described, namely: a pilot project of training using an author's distance course that highlights the effectiveness of creative communicative and professionally oriented tasks; team-competitive training; monitoring of the educational process. The program of distance course of the Ukrainian language and its structure is characterized. It is shown that the creation of a constant communicative process with elements of cooperation significantly increases the motivation for performing tasks for independent work and ensures the personal inclusion of students in continuous information and speech activities in the interactive mode of tasks. The effectiveness of the combined type of training is proven. A number of arguments are given to prove that the introduction of distance learning will contribute to the successful adaptation of foreign students to studying at universities in Ukraine.
Постановка проблеми. Інтенсивні темпи розвитку сучасних інформаційних технологій привносять відповідні корективи до різних сфер життя та діяльності людини. Велика кількість одержуваної інформації змінює спосіб людського мислення, а також швидкість та якість засвоювання нових знань. У першу чергу це стосується сучасної молоді, а саме студентів, які є основними одержувачами знань та які не уявляють свого життя без різноманітних девайсів та технічних пристроїв. Такі зміни у сприйнятті нових матеріалів значно впливають і на спосіб їх отримання: у процесі навчання переважним стає використання інформаційно-комунікаційних технологій.

Оскільки здобуваючи освіту в Україні, іноземні студенти навчаються іноземною для них мовою (українською чи англійською), особливого значення набуває процес їх мовної підготовки, а головним завданням цього процесу виявляється формування комунікативної компетентності. Урахування сучасних запитів новітнього суспільства до освітнього процесу вимагає оновлення сучасних навчальних технологій, зокрема лінгводидактики, разом із тим виникає необхідність 
використання новітніх засобів формування комунікативної компетентності іноземних студентів, які навчаються у ЗВО України.

Означені тенденції призвели до формування глобального інформаційного простору. В умовах створення мобільності світових освітніх систем для України все більш актуальним стає дистанційне навчання. Це пов'язано з тим, що «система дистанційної освіти дозволяє найширше i найповніше використовувати всі навчальні можливості інформаційних технологій» [6]. Останніми роками в Харківському національному автомобільно-дорожньому університеті та Харківському національному університеті імені В.Н. Каразіна з'явилися іноземні студенти заочної форми навчання освітньо-кваліфікаційного рівня «бакалавр», які потребують освітніх послуг за допомогою дистанційного навчання. Для цих іноземних студентів мовою навчання $є$ українська, у зв'язку із чим виникла необхідність створення дистанційного курсу з української мови для іноземних студентів-нефілологів заочної форми навчання, головною метою якого є формування комунікативної компетентності в соціокультурній і навчально-професійній сферах спілкування.

Мета статті. Проблеми впровадження електронних дистанційних курсів у навчальний процес ЗВО досліджують такі вчені України, Росії, Казахстану, як А.Н. Анісімов, А.Х. Гільмутдінов, Р.А. Ібрагімов, І.В. Цивільський та інші. Різні аспекти дистанційного навчання російської мови як іноземної висвітлюються в дослідженнях А.Н. Богомолова і О.А. Ускової [3], які зробили огляд вітчизняних і зарубіжних інформаційних технологій і методик «Дистанційне навчання російської мови як іноземної». Ученими розглядаються технології створення ресурсів дистанційного навчання російської мови як іноземної. Уважаємо доцільним під час створення дистанційного курсу з української мови для іноземних студентів технічних спеціальностей використовувати наявні теоретичні розробки.

Застосування засобів дистанційної освіти під час навчання української мови як іноземної ще не було предметом окремих наукових розвідок, корисним буде урахування досвіду іноземних методистів навчання російської мови як іноземної.

У дослідженнях зазначено, що дистанційне навчання має ряд переваг: доступність курсу в будь-який момент; необмеженість наданої інформації; оперативність надання інформації; гнучкість організації навчального процесу; автоматизація навчального процесу; мультимедійність. Перелічені переваги обгрунтовують доцільність використання дистанційних засобів під час формування україномовної комунікативної компетентності іноземних студентів українських ЗВО.
Мета статті - проаналізувати переваги та недоліки використання засобів дистанційної освіти під час навчання української мови іноземних студентів нефілологічних спеціальностей.

Виклад основного матеріалу дослідження. У теперішній час дистанційна освіти стрімко набуває популярності як в Україні, так і у всьому світі у цілому. Науковцями було створено концепцію дистанційного навчання [1] та визначено форми ії реалізації. «Під дистанційним навчанням розуміється індивідуалізований процес придбання знань, умінь, навичок і способів пізнавальної діяльності людини, який відбувається переважно при опосередкованій взаємодії віддалених один від одного учасників навчального процесу в спеціалізованому середовищі. Таке навчання функціонує на базі сучасних психолого-педагогічних та інформаційно-комунікаційних технологій» [8]. Використання означених технологій дозволить створити систему безперервного навчання української мови іноземних студентів-заочників.

«Метою дистанційного навчання $є$ надання освітніх послуг за допомогою застосування в навчанні сучасних інформаційно-комунікаційних технологій за певними освітніми або освітньо-кваліфікаційними рівнями відповідно до державних стандартів освіти; за програмами підготовки громадян до вступу до навчальних закладів та підготовки іноземців» [8].

Отже, для надання освітніх послуг повною мірою 3 мови навчання (української) для студентів-заочників нефілологічних спеціальностей нами було розроблено та впроваджено до навчального процесу дистанційний курс 3 української мови. Для перевірки ефективності курсу застосовано такі методи: пілотний проект навчання 3 використанням авторського дистанційного курсу, що висвітлює ефективність творчих комунікативних i професійно-орієнтованих завдань; командно-змагальне навчання; моніторинг навчального процесу.

1. Учасники. Навчаючись за авторським курсом «Українська мова для іноземних студентів-нефілологів», студенти мають можливість тренувати та практикувати комунікативні вміння в невеликих групах або парно. Це допомагає студентам розвинути здатність працювати командою (слухати, висловлювати думки, домовлятися і т.д.) і самостійно (зосередитися на часовому менеджменті та вирішенні проблем), а також сприяє розвитку вмінь самостійного навчання та пошуку нової інформації українською мовою, самооцінки результатів навчання.

Навчальний експеримент було проведено в Харківському національному університеті імені В.Н. Каразіна в 2016 році. У ньому взяли участь 29 студентів-нефілологів як заочної, так і стаціонарної форми навчання. Останні користувалися 
платформою дистанційного курсу, виконуючи самостійну роботу в кількості годин відповідно до факультетських навчальних планів університету. Звернемо увагу: всі учасники експерименту володіли базовим рівнем російської мови, що зумовило певну методичну орієнтацію в організації мовного матеріалу дистанційного курсу з української мови. Висновки експерименту довели, що учасники досягли необхідного рівня володіння українською мовою, який забезпечить оволодіння іноземними студентами вміннями в перцептивних і продуктивних видах мовленнєвої діяльності у сфері навчально-професійного спілкування; здобуття іноземними студентами мовних та професійно орієнтованих знань для реалізації комунікативної мети й задоволення необхідних комунікативних потреб у сфері навчально-професійного спілкування.

2. Anapam ma матеріали. Програма дистанційного курсу української мови має структуру і зміст ідентичні програмі денної форми навчання, але розрахована на кількість годин і кредитів, виділених нормативними документами для заочної форми навчання. Згідно з вимогами до структури дистанційного курсу він повинен містити матеріал, достатній для оволодіння студентом повним обсягом знань, умінь і навичок, передбачених навчальною програмою дисципліни [2]. Такий підхід дає можливість іноземним студентам-заочникам отримувати знання й удосконалювати комунікативні вміння 3 курсу «Українська мова для іноземних студентів-нефілологів» в обсязі не меншому, ніж отримують студенти денної форми навчання.

Застосований в експериментальному навчанні дистанційний курс має прозору структуру, яка містить такі елементи: 1) загальна інформація про дисципліну, що вивчається; 2) набір рекомендацій для студентів стосовно послідовності і терміну вивчення матеріалів як всієї дисципліни, так і їі окремих елементів; 3) загальні рекомендації щодо порядку виконання різних видів навчальної, практичної та самостійної роботи студента; 4) загальні критерії оцінювання знань, умінь і навичок, які повинен отримати студент у процесі навчання, $\mathrm{i}$ система оцінювання знань, умінь і навичок студента; 5) змістовний навчальний та навчальнометодичний матеріал; 6) методичні рекомендації з організації самостійної роботи студента, які стосуються засвоєння навчального матеріалу і виконання всіх видів навчальної роботи; 7) форми i терміни інтерактивної взаємодії студентів i викладача протягом семестру; 8) набори завдань і тестів для перевірки та контролю знань, умінь і навичок студентів у процесі вивчення дисципліни (проміжний контроль); 9) приклади правильних відповідей до всіх завдань із перевірки знань студента; 10) веб-ресурси та програмне забезпечення, які необхідні для виконання практичних видів навчальної роботи; 11) система інтерактивного спілкування студентів між собою.

Усі описані елементи поєднуються в чотири блоки: інструктивний, інформаційний, комунікативний і контрольний.

Інструктивний блок представлено елементом «Сценарій курсу», до якого включено рекомендації для студентів щодо послідовності та часу вивчення матеріалу й умов проведення поточного та підсумкового модульного контролю.

Інформаційний блок має два складники: теоретичний матеріал, який відібрано згідно з вимогами Програми дистанційного курсу, та практичні завдання (для формування комунікативної компетентності іноземних студентів). Завдяки цьому блоку студенти знайомляться 3 основними аспектами теми, що вивчається, та виконують практичні завдання, ураховуючи інструкції, підготовлені викладачем. Мультимедійні технології дають викладачу широкі можливості подачі матеріалу курсу та створення іншомовного комунікативного простору.

Комунікативний блок існує у вигляді форуму, на якому студенти можуть отримувати та обговорювати новини про організацію навчання в межах курсу української мови в режимі offline, i чату, створеного для проведення консультацій у режимі online.

Контрольний блок (поточний тематичний контроль) передбачає перевірку та оцінювання рівня сформованості комунікативної компетентності іноземних студентів. Для ознайомлення студентів із системою оцінювання їм пропонується детально вивчити такий елемент курсу, як «Шкала оцінювання», що містить таблицю та коментарі.

3. Процедура. Упроваджуваний дистанційний курс «Українська мова для іноземних студентів-нефілологів» дозволив створити мікросоціальну навчальну мережу, наприклад, у чаті для обговорення викладачем і студентами організаційних питань. Через цю мережу відбувається виконання комплексу завдань, спрямованих на формування комунікативної компетентності студентів-іноземців: 1) мовні, трансформаційні, підстановлювальні, питально-відповідні, умовно-мовленнєві та мовленнєві вправи (за класифікацією Ю.І. Пасова); 2) персоніфіковані рольові ігри; 3) проблемні завдання.

Створення постійного комунікативного процесу 3 елементами співпраці значно підвищило мотивацію виконання завдань для самостійної роботи. Таким чином було забезпечено особистісну включеність студентів у безперервну інформаційно-мовленнєву діяльність в інтерактивному режимі виконання завдань, їх публічної презентації та оцінки в мікросоціальній навчальній мережі. 
Етап публічної презентації та оцінки дозволив використати засоби оцінки навчальних досягнень іноземних студентів-філологів після виконання самостійної роботи.

Наведемо приклад реалізації перелічених вище елементів дистанційного курсу 3 розмовної теми «Моя родина».

Для засвоєння зазначеної розмовної теми необхідне вивчення граматичного мовного матеріалу 3 теми «Рід і число іменника» та опанування активної лексики (дідусь, бабуся, батько, мати, онук, онука і т.д.; інженер, викладач, вчителька, і т.п.; учень, студент) з названої розмовної теми, після чого іноземні студенти отримали такі завдання для самостійної роботи:

1) робота за зразком: у чаті групи викладачем розміщувалося посилання на електронний підручник і перелік завдань, спрямованих на автоматизацію навичок уживання вивчених граматичних форм iз використанням активної лексики розмовної теми;

2) конструктивно-варіативна самостійна робота полягала в тому, що студенти мали: зв'язатися через соцмережі з українськими одногрупниками та розпитати в них про їхні родини, обговорити у груповому чаті, з елементами міні-змагання, які українські родини є найцікавішими за сферою професійної діяльності їхніх членів (такі завдання дозволили сформувати та вдосконалити мовленнєві вміння завдяки переносу навичок у нові мовленнєві ситуаціi);

3) на етапі контролю студенти робили таке: презентація власного генеалогічного дерева на прикладі, поданому викладачем через посилання на певні джерела (у вигляді схеми або малюнка), а також підготовлене монологічне висловлювання про власну родину.

Процес та результати навчання за дистанційним курсом «Українська мова для іноземних студентів-нефілологів» виявили низку переваг i недоліків, які підтвердили спостереження попередніх дослідників [5;9].

Серед переваг дистанційного курсу було зафіксовано такі:

1) доступність курсу в будь-який момент (іноземні студенти-заочники мають можливість вільного доступу до теоретичного матеріалу курсу 3 російської мови у зручний для них час і самі обирають темп навчальної діяльності, але в межах зазначених модулів навчання);

2) необмеженість наданої інформації (мережа Інтернет дозволяє іноземним студентам під час вивчення курсу звертатись до великої кількості додаткових джерел);

3) оперативність надання інформації (електронні ресурси оновлюються частіше, ніж паперові);

4) гнучкість організації навчального процесу (дистанційне навчання дозволяє зосередитись на більш складних темах курсу, віддаючи прості елементи для самостійного вивчення);

5) автоматизація навчального процесу (немає необхідності складати велику кількість однотипних варіантів завдань для тесту і перевіряти результати їх виконання: система підбере будьякі параметри за бажанням викладача і здійснить перевірку і збереження результатів у журналі);

6) мультимедійність (крім традиційної текстової та графічної інформації, дистанційне електронне навчання природним чином припускає використання в процесі утворення методичних матеріалів усіх можливостей мультимедіа: анімації, відео, звуку і кольору, що забезпечує наочність подачі матеріалу і дозволяє задіяти більшість механізмів сприйняття людиною нової інформації, сприяючи підвищенню ефективності навчального процесу);

7) сприяє формуванню загальнонавчальної комnетенції (дистанційне навчання надає значно більше можливостей для самостійної роботи студента, сприяючи формуванню навичок самоорганізації та раціонального планування навчального часу).

Але, незважаючи на всі переваги, електронне дистанційне навчання має такі недоліки: високі вимоги до самоорганізації і самоконтролю учнів; надмірно формалізовані процеси навчання і перевірки знань, що істотно ускладнює забезпечення індивідуального підходу; вкрай обмежений обсяг практичних занять; виключення з процесу прямого мотивуючого впливу з боку викладача, яке має місце в аудиторній роботі, а також неможливість миттєвого зворотного зв'язку з педагогом, коли необхідно отримати моментальну допомогу; відсутність можливості висловити свою думку в усній формі; формальність навчання і перевірки знань.

Для підвищення ефективності використання засобів дистанційного навчання К.Г. Кречетниковим запропоновані рекомендації, «перевірені практикою» [6]:

1) надання необхідного тону роботи із самого початку курсу; ретельне і детальне планування діяльності студента, ii організації; чітка постанова завдань і цілей навчання;

2) підвищення ступеню інтерактивності електронних підручників; забезпечення зворотного зв'язку за допомогою електронної пошти, факсу, аудіо- та відеоконференцзв' язку, телефону;

3) час спілкування студентів із викладачем має бути максимально тривалим і зручним для суб'єктів навчального процесу;

4) розвиток у студентів необхідних навичок: технічних; управління дискусією; самостійного навчання; критичного мислення; управління інформацією, іiі відбору та критичної оцінки;

5) структура курсу має бути блочно-тематичною: студент повинен чітко усвідомлювати своє просування від теми до теми. 
Для усунення недоліків, які було віднайдено під час експериментального навчання, надалі впроваджується така заочно-дистанційна форма навчання, за допомогою якої студенти отримують знання $з$ дисципліни «Українська мова» засобами електронних дистанційних курсів, але підсумковий контроль проводиться лише у присутності викладача під час очних сесій. Адже вважаємо доцільним застосовувати комбіновану дистанційно-заочну форму навчання, яка поєднує традиційність $з$ інноваційністю.

Структура курсу «Українська мова для іноземних студентів-нефілологів», яку описано вище, дозволяє комбінувати дистанційну форму навчання й традиційну, що значно підвищує ефективність організації навчального процесу іноземних студентів нефілологічних спеціальностей i сприяє успішній адаптації означеного контингенту до навчання у ЗВО.

Висновки. Таким чином, описані вище вимоги до укладання дистанційних курсів, переваги та недоліки, структура дистанційного курсу з української мови для іноземних студентів нефілологічних спеціальностей, розроблена на основі наявних програм та з урахуванням вимог до створення електронних дистанційних курсів, обгрунтовують доцільність обраного шляху укладання та застосування дистанційних курсів у технічних 3ВО. Такі дистанційні курси допомагають задовольнити освітні потреби студентів заочно-дистанційної форми навчання, забезпечують поступове засвоєння матеріалів курсу та дозволяють створити віртуальне іншомовне середовище, що підвищує ефективність процесу навчання української мови як іноземної.

Перспективою подальших досліджень може стати розроблення принципів створення навчального дистанційного веб-квест комплексу з української мови як іноземної, який сприятиме задоволенню комунікативних потреб іноземних студентів-нефілологів у позааудиторний час та забезпечуватиме самостійну роботу студентів усіма необхідними навчальними матеріалами.

\section{ЛIТЕРАТУРА}

1. Аксенов Ю.В., Петров А.Е., Полат Е.С. Концепция дистанционного обучения на базе компьютерных телекоммуникаций. URL : http://www.phis.org.ru/education/ saityobr.shtml.

2. Андреев А.А. Введение в дистанционное обучение : учебно-методическое пособие. Москва : BУ, 1997. $197 \mathrm{c}$.

3. Богомолов А.Н., Ускова О.А. Дистанционное обучение русскому языку как иностранному: обзор отечественных и зарубежных информационных технологий и методик. Москва : ЦМО МГУ, 2004. 74 с.

4. Вимоги до структури дистанційного курсу, затверджені рішенням Координаційної ради 3 питань електронного (дистанційного) навчання Харківського національного університету імені В.Н. Каразіна від 08.10.2013 р. Протокол № 2. URL : http://dist.karazin.ua/moodle/course.

5. Гильмутдинов А.Х., Ибрагимов Р.А., Цивильский И.В. Электронное образование на платформе Moodle. Казань: КГУ, 2008. URL : http://dist.karazin.ua/moodle/course.

6. Кречетников К.Г., Черненко Н.Н. Дистанционное обучение. Достоинства, недостатки, вопросы организации (аналитический обзор). Интернет-журнал «Эйдос». 2001. 20 марта. В надзаг: Центр дистанционного образования «Эйдос», e-mail:list@eidos.ru. URL : http://www.eidos.ru/journal/2001/0320.htm.

7. Малитиков Е.М., Карпенко М.П., Колмогоров В.П. Дистанционное образование в Российской Федерации и странах СНГ: вопросы теории и практики. Телекоммуникации и информатизация образования. 2001. № 3. С. 16-36.

8. Про затвердження Положення про дистанційне навчання. Наказ МОН України, Положення від 25.04.2013 № 466. URL : http://zakon2.rada.gov.ua/laws/show/z0703-13.

9. Чеботарёва О.И. Методика адаптации учебных материалов для очно-дистанционного обучения английскому языку : автореф. дис. канд. пед. наук: 13.00.02. - теория и методика обучения и воспитания (русский язык как иностранный и иностранные языки в общеобразовательной и высшей школе). ФГОУ ВПО «Московский государственный университет имени М.В. Ломоносова». Москва, 2012. 26 с.

10. Alahuhta, P., Nordbäck, E., Sivunen, A., \& Surakka, T. (2014). Fostering team creativity in virtual worlds. Journal of Virtual Worlds Research, 7(3), 1-22. Retrieved March, 25, 2018. URL : https://journals.tdl.org/ jvwr/index.php/jvwr/article/view/7062.

\section{REFERENCES}

1. Aksenov Iu.V, Petrov A.E., Polat E.S. (1998). Koncepcija distancionnogo obuchenija na baze komp'juternyh telekommunikacij [The concept of distance learning on the base of computer telecommunications]. http://www.phis.org.ru/education/ saityobr.shtml [in Russian].

2. Andreev A.A. (1997). Vvedenie $\mathrm{v}$ distancionnoe obuchenie: uchebno-metodicheskoe posobie [Introduction to distance learning: a manual]. - Moscow: VU. 197 p. [in Russian]. 
3. Bogomolov A.N., Uskova O.A. (2004). Distancionnoe obuchenie russkomu jazyku kak inostrannomu: obzor otechestvennyh i zarubezhnyh informacionnyh tehnologij i metodik [Distance learning of the Russian language as a foreign language: a review of native and foreign information technologies and techniques]. - Moscow: TSMO MGU. - 74 p. [in Russian].

4. Vymohy do struktury dystantsiinoho kursu, zatverdzheni rishenniam Koordynatsiinoi rady z pytan elektronnoho (dystantsiinoho) navchannia Kharkivskoho natsionalnoho universytetu imeni V.N. Karazina vid 08.10.2013 r. [Requirements for the structure of the distance course, approved by the decision of the Coordination Council on questions of electronic (distance) education of the V.N. Karazin Kharkiv National University of 08.10.2013.] Protocol № 2. http://dist.karazin.ua/moodle/course [in Ukrainian].

5. Gilmutdinov A.Kh., Ibragimov R.A. Tsivilskii I.V. (2008). Elektronnoe obrazovanie na platforme Moodle [E-learning on the Moodle platform]. - Kazan: KGU. https:/ua1lib.org/book/749171/0666c5?id=749171 \&secret $=0666 \mathrm{c} 5$ [in Russian].

6. Krechetnikov K.G., Chernenko N.N. (2001). Distancionnoe obuchenie. Dostoinstva, nedostatki, voprosy organizacii (analiticheskij obzor). [Distance learning. Advantages, disadvantages, questions of organization (analytical review)] http://www.hr-portal.ru/article/distantsionnoe-obuchenie-dostoinstva-nedostatkivoprosy-organizatsii-krechetnikov-k-g-cherne [in Russian].

7. Malitikov E.M, Karpenko M.P., Kolmogorov V.P. (2001). Distancionnoe obrazovanie v Rossijskoj Federacii i stranah SNG: voprosy teorii i praktiki [Distance education in the Russian Federation and CIS countries: questions of theory and practice]. Telekommunikacii i informatizacija obrazovanija-Telecommunications and informatization of education, 3, 16-36. [in Russian].

8. Pro zatverdzhennia Polozhennia pro dystantsiine navchannia. Nakaz MON Ukrainy, Polozhennia vid 25.04.2013 № 466. [Order of the Ministry of Education and Science of Ukraine "On Approval of the Regulations on Distance Learning. № 466, 25.04.2013] http://zakon2.rada.gov.ua/laws/show/z0703-13 [in Ukrainian].

9. Chebotareva O.I. (2012). Metodika adaptacii uchebnyh materialov dlja ochno-distancionnogo obuchenija anglijskomu jazyku [Methods of adaptation of educational materials for full-time and distance learning in English]. Abstract of dis....cand. ped. sciences: 13.00.02. Lomonosov Moscow State University, Moscow. 26 p. [in Russian].

10. Alahuhta, P., Nordbäck, E., Sivunen, A., \& Surakka, T. (2014). Fostering team creativity in virtual worlds. Journal of Virtual Worlds Research, 7(3), 1-22. Retrieved March, 25, 2018 from https://journals.tdl.org/ jvwr/index.php/jvwr/article/view/7062 [in English]. 